\title{
Troponin I, Cardiac Muscle
}

National Cancer Institute

\section{Source}

National Cancer Institute. Troponin I, Cardiac Muscle. NCI Thesaurus. Code C104226.

Troponin I, cardiac muscle (210 aa, $\sim 24 \mathrm{kDa}$ ) is encoded by the human TNNI3 gene. This protein is involved in muscle filament movement in cardiac cells. 